\title{
THE COMPARISON OF THE DEMOGRAPHIC CHARACTERISTICS OF THE PARTICIPANTS IN TERMS OF PARTICIPATION MOTIVES TO DIFFERENT EVENTS
}

\section{KATILIMCILARIN DEMOGRAFIK ÖZELLIKLERININ FARKLI ETKİNLIKLERE KATILIM GÜDÜLERİ AÇISINDAN KARŞILAŞTIRILMASI}

Ebru GUNLU, Dokuz Eylul University, Turkey, ebru.gunlu@deu.edu.tr

Ceyda LALE, Izmir University, Turkey, lalceyda@gmail.com

\begin{abstract}
The researches that are conducted in the discipline of tourism recently have pointed out that the motives of the participants play a determinative role in the management of the events. The underlying motives for participating an event and the demographic characteristics of the visitors can make an important contribution both for the planning process and the marketing studies of the events. The aim of this study, is to classify the motives of the individuals according to the type of events that are participated in Izmir, in this context, data have been collected from the event participants who have joined the events which are organised in the provincial borders of Izmir by using the questionnaire technique. The visitors that have participated in the film, flower and boyoz (a pastry that is associated with Izmir) festivals in Izmir constitute the universe of the research , 460 questionnaires have been obtained as 175 from the film festival, 141 from the flower festival and 144 from the boyoz festival. As a result of the research, it is determined that the motives of the
\end{abstract} participation in the events differentiate according to the types of the events.

Keywords: Event, Motive, Tourist Behaviour, Event Management, İzmir

Öz: Turizm disiplininde son dönemde yapılan araşttrmalar özellikle etkinliklerin yönetiminde etkinliğe katılan bireylerin güdülerinin belirleyici rol üstlendiğini işaret etmektedir. Etkinliklere katılan ziyaretçilerin etkinliklere katıllm güdülerinin araştırllması, araştırmalar sonucunda ziyaretçilerin demografik özelliklerinin ve katılım güdülerinin belirlenmesi, etkinliklerin planlanması ve pazarlama çalı̧̧maları açısından önemli bir katkı sağlamaktadır. Bu çalışmanın amacı da İzmir'de etkinliklere katılan bireylerin güdülerini etkinlik türüne göre sinıflandırmaktır. Bu kapsamda, İzmir il sinırları içerisinde düzenlenen etkinliklere katılan ziyaretçilerden anket tekniği kullanılarak veri toplanmıştır. Araşstırmanın evrenini, çalışmanın yürütüldüğü dönemde İzmir'de düzenlenen film, çiçek ve boyoz festivaline katılan ziyaretçiler oluşturmuş ve araştırma sonucunda film festivaline ait 175, çiçek festivaline ait 141 ve boyoz festivaline ait 144 ziyaretçi olmak üzere toplamda 460 adet anket elde edilmiştir. Araştırma sonucunda, etkinliklere katılan ziyaretçilerin katıllm güdülerinin etkinlik türlerine göre farklllık gösterdiği belirlenmiștir.

Anahtar Kelimeler: Etkinlik, Güdü, Turist Davranışı, Etkinlik Yönetimi, İzmir

\section{Introduction}

Events are important touristic attractions that draw interest of large masses due to the events' bearing a touristic attraction, and for their impact on the attraction center, the event concept have taken its place in the discipline of tourism. Even though the event concept has well-known, the "event tourism" concept have started to gain importance in 1980's and took its place as an compact research field after the 2000's. (Getz, 2008:409411). 
While the sea, sand, sun was the most important tourism type in the past, nowadays, it has lost its popularity, and different tourism types have started to gain importance. In this context, the event tourism which has developed rapidly in recent years, is taking its place on the stage as an importance touristic product, and it is also evaluated as an important means in the point of the protection, expansion and sharing of the cultural values. Especially, the different event types' being associated with different motives has importance in the issue of the management and marketing of the events, as well. The researches which have been made in recent years indicate that the motives of the individuals participating in an event, play a determining role in the management of the events.(Backman et al., 1995; Chang, 2006; Crompton and Mackay, 1997; Formica and Uysal, 1996, 1998; Lee, 2000; Lee et al., 2004; McMorland and MacTaggart, 2008; Mohr et al., 1993; Schneider and Backman, 1996; Scott, 1996; Uysal et al., 1993). Starting from this point of view, investigating the motives of the visitors that participate in events and determining the demographic characteristic could make important contributions with regard to the planning and marketing of the events.

\section{Review of Literature}

The development of technology, the increase in the trading volume among countries and changing consumer behaviour have resulted with fiercecompetition considerably in recent years and especially draw attention to the human factor in the service sector. While the "Individual" and the "Expectation of the Individual" coming into prominence, the mentioned need for the satisfaction of the individual, certainly have a crucial importance with regard to the competitive advantage. (Alan, 2006:15) The endeavour of satisfying the individual, gains meaning by starting from the expectations and the motives of the individiual.

As tourism activities mainly focus on the behaviour of the individuals, they are also closely associated with the individualistic features. Some inborn motives are effective in orienting the tourism behaviour of the individuals. The need for a change and novelty are the most important ones among those Relaxation which is another inborn motive, also affect the tourism behaviour. Sometimes, tourism may be an effective means in satisfying the learned motives such as earning respect. (Doğan, 2004:5-6). Tourist motivation; is defined as combining the physiological and cultural powers globally, which give direction to the travelling options, behaviours and experiences (Singh, 2008:34 cited from Pearce et al., 1998) .

Koçel (2010:619) defines the motivation as "the individuals' behaving and endeavouring with their own claim and wish to realize a certain aim". The motivation is "an inner feeling which is caused by the need, claim and wishes of the individuals revealed by their physical and mental energies for to reach the desired targets." (Kondalkar, 2009:243)

The revealing of the travelling needs in connection with the motives, is realized under certain conditions. This connection is based on an influencing, learning process. The individual puts his needs and motives in a value order in connection with his various experiences; he wants to reach the aims which have priority especially for himself. Thus, the transformation of various motives into a tourism behaviour, involves a decision-making process (Doğan, 2004:7). If the tourists are seen as consumers, the tourism demand is formulated as the consumer decision-making process. (Hall ve Page, 2006:87) Within this framework, for to understand the motivation of the tourists, the factors that motivate the tourists should be taken into consideration, as well.

The factors which direct the individuals to touristic behaviour and events, vary. Particularly, in modern-day tourism activities, the number of the factors which constitute this diversity is quite a few. According to an approach, these factors are collected in two groups; a) inner factors, the causes which create the need of the people to travel out of the place they are living in and to accommodate. While the factors such as the business, curiosity, religion, culture, education, relaxation and entertainment, sports, health, tendency to immitate (Snobizm), visiting the friends and relatives, congress and meetings are listed in this scope (Olalı and Timur, 1988:20-21; Usta, 2009:16-17), b) the external factors are accepted as the marketing communication (promotion) and the opening of the new touristic regions to tourism.

In the basis of the researches and the approaches, which are made in the discipline of the tourism, there is the Maslow's Need Hierarchy. When Maslow Hiyerarchy is evaluated in terms of the touristic behaviour, it is possible to say that ; a) the travels made with the aim of relaxation, food \& beverage, health and entertainment are associated with the physiological needs, b) the travels made with the aim of visiting relatives, yearning the ancestors, getting rid of the feeling of loneliness and making friends, are associated with the needs of loyalty; c) the travels made with the aim of searching status and earning respect are associated with the needs of ego(self); d) the travels made with the aim of dealing with science, making sports, creating work of art, enhancing knowledge and experience, seeing different places, changing, novelty, learning different things, to prove existence, taking more satisfaction from life, are all associated with the needs of realizing oneself. Thus, it is 
seen that the motivating factors are effective in the formation of the tourism behaviour (Doğan, 2004:15-16; Rizaoğlu, 2003:72-73).

Philip L. Pearce (Ryan, 1998:936 cited from 1988), introduced the idea of the career ladder which emphasize the Maslow's motivation theory together with the travelling motives hierarchy. The career ladder emphasizes the people who have some motives searching for a vacation experience. The Travel Career Ladder which has different levels, permits so many motives, and is also dynamic. In an another aspect, it analyzes different levels. It especially gives clues about the needs of relationship, self-respect, self-realization (Singh, 2008:248-249).

Pearce and et al., developed the Travel Career Ladder by adding the Travel Career Model to it, as well. Pearce asserted that as the life level of the people changes, the motivating model also changes. Pearce and Lee (2005:227-236), listed fourteen items of motivation factor on tourist behaviour; a) novelty, b) escaping/relaxation, c) endurance relationship, d) independency, e) nature f) self-development (opposite party) g) impulse, h) self-development (personal growth ), i) security relationship, j) self-realization, k) yearning fort the past, $\mathrm{m}$ ) attraction, and $\mathrm{n}$ ) recognition.

While the Event Tourism is defined as the "organising, planning, marketing the event which attracts the visitors and the systematic development (Tassiopoulos, 2005:4)"; Masberg (Tassiopoulus, 2005:5 cited from 1998:67) defines the event visitor as the "persons who travel for business, pleasure or other personal reasons to a distant place and stay overnight in a center of attraction". In fact, the individuals, who travel or spend part of their travel to this event, are being mentioned.

In recent years, the event tourism preserves its place of being a research subject developing in the tourism discipline. The motives of participating in an event's carrying importance in the event management, have caused so many researchers to deal with the motives of participating in the events. Ralston and Crompton (1988), in the study they had made, dealt with the "1987 Dickens on the Strand Festival" which was also mentioned as the holiday festival telling about the history of the queen. In this event, the dimensions of family togetherness, meeting new people or observing people, nostalgia, learning and discovering, social links, searching for doing something, escaping from the personal and social pressures, revealed.

In their study, Uysal et al. (1993) examined the "1991 Travellers Rest's Country Corn Festival" concerning the food and determined the dimensions of escaping, excitement/pleasure, new events, socializing and family togetherness. Mohr et al. (1993) in their study dealt with the "Freedom Weekend Aloft, a Hot Air Balloon Festival" which was a festival about special hobbies, the dimensions of socializing, family togetherness, excitement/ extraordinary, escaping, new events; in the study which Formica and Uysal (1996) dealt with the '1995 Umbria Jazz Festival"' which was a cultural event, the dimensions of excitement/pleasure, socializing, new events, family togetherness gained attention. In the "Italy Spoleto Festival" which was done in the year of 1998, and was constituted from the music and opera, the dimensions revealed were the socializing ve entertainment, the event attraction/excitement, group togetherness, cultural/historical and family togetherness.

Nicholson and Pearce (2001) scrutinized different events and determined the stated dimensions respectively; a) Malborough Wine, Food and Music Festival: Socializing, uniqueness relation/change, escape and family;b)Hokitika Wildfoods Festival: Socializing, uniqueness relation/change, entertainment/excitement/human, escaping and family ; c) Wardbirds over Wanaka Festival: uniqueness relation/change, socializing, details, escaping and family; d) New Zealand Golden Guitar Awards: details/entertainment, escaping, diversity, uniqueness relation, family and socializing.

Lee et al. (2004), in the study they had realised, while in the 2000 Kyongju World Cultural Expo, obtaining the dimensions of the cultural discovery, family togetherness, change, escaping, attraction of the event and socializing; Yuan et al. (2005) fixed the dimensions of the escaping, wine, socializing and family togetherness in the Vintage Indiana Wine and Food Festival which they dealt with . Also, in the South Beach Wine and Food Festival in the Miami Beach, Park and et al. (2008), they revealed the dimensions of tasting new wine and food, liking event, raising the social status, escaping from the routine life, meeting new people, spending time with the family, meeting celebrities and meeting wine experts. Whereas Chang (2011), while examining the 'Food Festival Texas event, have found out the dimensions of wine, escaping/event change, food, known group socializings, external sociability, art.

All these researches indicate that, when the research aims and findings are taken into consideration, investigating the motives of participating in the events, segmentation of the demographic characteristics and the participation motives of the visitors can make considerable contribution in respect to the planning of the events and marketing studies.

Starting from this point of view, the research question in this study is determined as ;

"Are the visitors who participate in different events organised in Izmir differentiate as per the type of the event they participate in, depending upon the demographic characteristics that they own?"and the below hypotheses are formed. 
Snipes and Ingram (2007), Thompson and Schofield (2009), Yuan et al. (2005), in their researches, stated that the motive of the participation in an event, revealed difference as per the genders of the visitors.

H1: The motives of the participation in the event reveal difference as per the genders of the visitors.

Park (2009), Snipes and Ingram (2007), Thompson and Schofield (2009) and Yuan et al. (2005) stated that the motive to participate in an event revealed difference as per the ages of the visitors.

$\mathrm{H} 2$ : The motives to participate in an event reveal difference as per the ages of the visitors.

Yuan et al. (2005) stated that the motives to participate in an event revealed difference as per the family type of the visitors participating in an event.

H3: The motives to participate in an event reveal difference as per the family type of the visitors.

Snipes and Ingram (2007), Yuan et al. (2005) stated that the motive of participating in an event revealed difference as per the education of the visitors participating in the event.

H4: The motives of participating in an event reveal difference as per the education level of the visitors.

Yuan et al. (2005) stated that the motives of participating in an event revealed difference as per the monthly family income of the visitors participating in the event.

H5: The motives of participating in an event reveal difference as per the family income of the visitors.

\section{The Method of the Research}

\subsection{Scale and Sampling}

The main population of the research involves the visitors which have participated in the events that were organised in the provincial borders of Izmir. With the aim of determining whether the participation motive of the visitors differentiate or not by making a comparison, three different events (the film festival, flower festival and the boyoz festival) were focused. . The events which are organised in the months of April and May were as follows:he $12^{\text {th }}$ International Izmir Film Festival ${ }^{1}$, the $15^{\text {th }}$ International Bayındır Flower Festival ${ }^{2}$, an event which is related with the special hobbies of individuals and the Izmir Boyoz Festival ${ }^{3}$, an event which is related with foods. By using random sampling a total of 460 questionnaire has been collected (175 from the film festival, 141 from the flower festival and 144 from the boyoz festival).

As the method of the research ise quantitative the questionnaire technique is preferred. Within this scope, the previous questionnaires conducted by Nicholson and Pearce (2001) for Malborough Wine, Food and Music Festival, Hokitika Wildfoods Festival, Wardbirds over Wanaka Festival, the New Zealand's Golden Guitar Awards are used. 3 items of the questionnaires were structured as different for each festival. The questionnaire was prepared by using 5 point Likert scale $(1=\mathrm{I}$ strongly disagree $2=\mathrm{I}$ disagree $3=\mathrm{I}$ neither agree or disagree $4=I$ agree $5=I$ strongly agree) and formed by three parts such as the a) the demographic information, b) event, information about the participation type and features, c) the visitor participation motive. The obtained data was analysed by SPSS.

As the $12^{\text {th }}$ International Izmir Film Festival which is involved in the scope of this research is a cultural event shows similarity with the New Zealand Golden Guitar Music Awards included in the researches of the Nicholson and Pearce (2001), the "15 $5^{\text {th }}$ International Bayındır Flower Festival" which are events about the special hobbies of the individuals show similarity with the Warbirds over Wanaka and the "1. Izmir Boyoz Festival" shows similarity with the Marborough Wine, Food and Music Festival and Hokikita Wildfoods Festival as type of events.

(http://www.haberekspres.com.tr/filmfestivali-odulunu-nar-aldi.htm, date accessed: 24.07.2012; http://www.gazete5.com/haber/12.-uluslararasi-izmir-filmfestivali-haberleri-207996.htm, date accessed: 24.07.2012).

\footnotetext{
1The 12th International İzmir Film Festival was organised between the years of 1989-2000 uninterruptedly, and after an 11 years' interval, it started again in the year of 21-28 April, 2012. Throughout one week, 103 films from over fifty countries were screened daily in 5 sessions. So many types of film, particularly the world films, short films, documentaries, the samples from the Dokuz Eylul University graduate movie-makers. Also, a photograph exhibition concerning the directors was held in the event. (http://www.haberekspres.com.tr/filmfestivali-odulunu-nar-aldi.htm date accessed: 24.07.2012; http://www.gazete5.com/haber/12.-uluslararasi-izmir-filmfestivali-haberleri-207996.htm, date accessed: 24.07.2012).

2 15th International Bayindir Flower Festival has acquired an international qualifications and was realised between the dates of 27-29 April 2012. Within the scope of the festival which has visitors nearly 1 million, the folk dance groups, the animation groups and street musicians stage performances besides organising kite festival and fireworks. (http://www.yeniasir.com.tr/KentHaberleri/2012/05/01/cicek-festivaline-1-milyonziyaretci, date accessed: 24.07.2012).

3 The Izmir Boyoz Festival was organised in the date of 6th May, 20132 and continued approximately for 4 hours. The Boyoz Eating, Music Concerts, dance groups were held in the event. (http: //www.yeniasir.com.tr/Sarmasik/2012/05/04/izmirin-simgesi boyozfestivalle-taclaniyor date accessed: 24.07.2012).
} 


\subsection{Demographic Variables}

With the aim of obtaining personal data about the visitors which participate in the research, a set of demographic questions are included in the the scale which contain the gender, age, residential address, family type, social status, education level and the monthly family income. The profile of the visitors that participated in the events within the scope of the Izmir city are in the below ;

Table 1: Demographic Characteristics of Visitors in Film Festival

\begin{tabular}{|c|c|c|c|c|}
\hline & Groups & $n$ & Percentage & $\begin{array}{l}\text { Cumulative } \\
\text { Percentage }\end{array}$ \\
\hline \multirow{3}{*}{ Gender } & Female & 96 & 54,9 & 54,9 \\
\hline & Male & 79 & 45,1 & 100,0 \\
\hline & TOTAL & 175 & 100,0 & \\
\hline \multirow{7}{*}{ Age } & $18-24$ & 67 & 38,3 & 38,3 \\
\hline & $25-34$ & 64 & 36,6 & 74,9 \\
\hline & $35-44$ & 23 & 13,1 & 88,0 \\
\hline & $45-54$ & 15 & 8,6 & 96,6 \\
\hline & $55-64$ & 4 & 2,3 & 98,9 \\
\hline & $65-74$ & 2 & 1,1 & 100,0 \\
\hline & TOTAL & 175 & 100,0 & \\
\hline \multirow{6}{*}{ Family Type } & Single & 98 & 56,0 & 56,0 \\
\hline & In a relationship & 36 & 20,6 & 76,6 \\
\hline & $\begin{array}{c}\text { Married wtihout } \\
\text { children }\end{array}$ & 15 & 8,6 & 85,1 \\
\hline & Married with children & 25 & 14,3 & 99,4 \\
\hline & Divorced with children & 1 & 0,6 & 100,0 \\
\hline & TOTAL & 175 & 100,0 & \\
\hline \multirow{15}{*}{ Social Status } & $\begin{array}{c}\text { 0ffice } \\
\text { personnel/Secretary }\end{array}$ & 26 & 14,9 & 14,9 \\
\hline & Entrepreneur & 2 & 1,1 & 16,0 \\
\hline & Unemployed & 7 & 4,0 & 20,0 \\
\hline & Student & 75 & 42,9 & 62,9 \\
\hline & Housewife & 3 & 1,7 & 64,6 \\
\hline & Retired & 11 & 6,3 & 70,9 \\
\hline & Academician & 9 & 5,1 & 76,0 \\
\hline & Teacher & 15 & 8,6 & 84,6 \\
\hline & Banker & 5 & 2,9 & 87,4 \\
\hline & Doctor & 4 & 2,3 & 89,7 \\
\hline & Lawyer & 3 & 1,7 & 91,4 \\
\hline & Self employment & 6 & 3,4 & 94,9 \\
\hline & Director & 3 & 1,7 & 96,6 \\
\hline & Police/ Soldier & 6 & 3,4 & 100,0 \\
\hline & TOTAL & 175 & 100,0 & \\
\hline \multirow{7}{*}{ Education Level } & Primary School & 1 & 0,6 & 0,6 \\
\hline & High School & 16 & 9,1 & 9,7 \\
\hline & Associate & 9 & 5,1 & 14,9 \\
\hline & Undergraduate & 108 & 61,7 & 76,6 \\
\hline & Postgraduate & 33 & 18,9 & 95,4 \\
\hline & Others (Phd etc.) & 8 & 4,6 & 100,0 \\
\hline & TOTAL & 175 & 100,0 & \\
\hline \multirow{3}{*}{$\begin{array}{c}\text { Monthly Family } \\
\text { Income }\end{array}$} & 700 TL and down & 1 & 0,6 & 0,6 \\
\hline & $701-1000 \mathrm{TL}$ & 27 & 15,4 & 16,0 \\
\hline & $1001-1500 \mathrm{TL}$ & 19 & 10,9 & 26,9 \\
\hline
\end{tabular}


Gunlu, E., Lale, C. / Journal of Yasar University, 2015, 10/40, 6730-6751

\begin{tabular}{|c|c|c|c|c|}
\hline \multirow{4}{*}{$1501-2000 \mathrm{TL}$} & 36 & 20,6 & 47,4 \\
\cline { 2 - 5 } & $2001-3000 \mathrm{TL}$ & 47 & 26,9 & 74,3 \\
\cline { 2 - 5 } & 3001 TL and above & 45 & 25,7 & 100,0 \\
\cline { 2 - 5 } & TOTAL & 175 & 100,0 & \\
\hline
\end{tabular}

Table 2: Demographic Characteristics of Visitors in Flower Festival

\begin{tabular}{|c|c|c|c|c|}
\hline & Groups & $n$ & Percentage & $\begin{array}{l}\text { Cumulative } \\
\text { Percentage }\end{array}$ \\
\hline \multirow{3}{*}{ Gender } & Female & 87 & 61,7 & 61,7 \\
\hline & Male & 54 & 38,3 & 100,0 \\
\hline & TOTAL & 141 & 100,0 & \\
\hline \multirow{7}{*}{ Age } & $18-24$ & 18 & 12,8 & 12,8 \\
\hline & $25-34$ & 18 & 12,8 & 25,5 \\
\hline & $35-44$ & 20 & 14,2 & 39,7 \\
\hline & $45-54$ & 38 & 27,0 & 66,7 \\
\hline & $55-64$ & 31 & 22,0 & 88,7 \\
\hline & $65-74$ & 12 & 8,5 & 97,2 \\
\hline & TOTAL & 4 & 2,8 & 100,0 \\
\hline \multirow{6}{*}{ Family Type } & Single & 141 & 100,0 & \\
\hline & In a relationship & 34 & 24,1 & 24,1 \\
\hline & $\begin{array}{c}\text { Married wtihout } \\
\text { children }\end{array}$ & 2 & 1,4 & 25,5 \\
\hline & Married with children & 6 & 4,3 & 29,8 \\
\hline & Divorced with children & 91 & 64,5 & 94,3 \\
\hline & TOTAL & 8 & 5,7 & 100,0 \\
\hline \multirow{15}{*}{ Social Status } & $\begin{array}{c}\text { 0ffice } \\
\text { personnel/Secretary }\end{array}$ & 141 & 100,0 & \\
\hline & Entrepreneur & 13 & 9,2 & 9,2 \\
\hline & Unemployed & 2 & 1,4 & 10,6 \\
\hline & Student & 2 & 1,4 & 12,1 \\
\hline & Housewife & 13 & 9,2 & 21,3 \\
\hline & Retired & 36 & 25,5 & 46,8 \\
\hline & Academician & 40 & 28,4 & 75,2 \\
\hline & Teacher & 1 & 0,7 & 75,9 \\
\hline & Banker & 2 & 1,4 & 77,3 \\
\hline & Doctor & 6 & 4,3 & 81,6 \\
\hline & Lawyer & 20 & 14,2 & 95,7 \\
\hline & Self employment & 6 & 4,3 & 100,0 \\
\hline & Director & 141 & 100,0 & \\
\hline & Police/ Soldier & 60 & 42,6 & 42,6 \\
\hline & TOTAL & 38 & 27,0 & 69,5 \\
\hline \multirow{7}{*}{ Education Level } & Primary School & 5 & 3,5 & 73,0 \\
\hline & High School & 32 & 22,7 & 95,7 \\
\hline & Associate & 5 & 3,5 & 99,3 \\
\hline & Undergraduate & 1 & 0,7 & 100,0 \\
\hline & Postgraduate & 141 & 100,0 & \\
\hline & Others (Phd etc.) & 5 & 3,5 & 3,5 \\
\hline & TOTAL & 40 & 28,4 & 31,9 \\
\hline \multirow{2}{*}{$\begin{array}{l}\text { Monthly Family } \\
\text { Income }\end{array}$} & 700 TL and down & 27 & 19,1 & 51,1 \\
\hline & $701-1000 \mathrm{TL}$ & 29 & 20,6 & 71,6 \\
\hline
\end{tabular}


Gunlu, E., Lale, C. / Journal of Yasar University, 2015, 10/40, 6730-6751

\begin{tabular}{|c|c|c|c|c|}
\hline \multirow{4}{*}{$1001-1500 \mathrm{TL}$} & 17 & 12,1 & 83,7 \\
\cline { 2 - 5 } & $1501-2000 \mathrm{TL}$ & 23 & 16,3 & 100,0 \\
\cline { 2 - 5 } & $2001-3000 \mathrm{TL}$ & 141 & 100,0 & \\
\cline { 2 - 5 } & $3001 \mathrm{TL}$ and above & 87 & 61,7 & 61,7 \\
\cline { 2 - 5 } & TOTAL & 54 & 38,3 & 100,0 \\
\hline
\end{tabular}

Table 3: Demographic Characteristics of Visitors in Boyoz Festival

\begin{tabular}{|c|c|c|c|c|}
\hline & Groups & $n$ & Percentage & $\begin{array}{l}\text { Cumulative } \\
\text { Percentage }\end{array}$ \\
\hline \multirow{3}{*}{ Gender } & Female & 94 & 65,3 & 65,3 \\
\hline & Male & 50 & 34,7 & 100,0 \\
\hline & TOTAL & 144 & 100,0 & \\
\hline \multirow{7}{*}{ Age } & $18-24$ & 77 & 53,5 & 53,5 \\
\hline & $25-34$ & 35 & 24,3 & 77,8 \\
\hline & $35-44$ & 8 & 5,6 & 83,3 \\
\hline & $45-54$ & 13 & 9,0 & 92,4 \\
\hline & $55-64$ & 11 & 7,6 & 100,0 \\
\hline & $65-74$ & 144 & 100,0 & \\
\hline & TOTAL & 73 & 50,7 & 50,7 \\
\hline \multirow{6}{*}{ Family Type } & Single & 36 & 25,0 & 75,7 \\
\hline & In a relationship & 2 & 1,4 & 77,1 \\
\hline & $\begin{array}{l}\text { Married wtihout } \\
\text { children }\end{array}$ & 27 & 18,8 & 95,8 \\
\hline & Married with children & 5 & 3,5 & 99,3 \\
\hline & Divorced with children & 1 & 0,7 & 100,0 \\
\hline & TOTAL & 144 & 100,0 & \\
\hline \multirow{15}{*}{ Social Status } & $\begin{array}{c}\text { Office } \\
\text { personnel/Secretary }\end{array}$ & 11 & 7,6 & 7,6 \\
\hline & Entrepreneur & 1 & 0,7 & 8,3 \\
\hline & Unemployed & 3 & 2,1 & 10,4 \\
\hline & Student & 76 & 52,8 & 63,2 \\
\hline & Housewife & 7 & 4,9 & 68,1 \\
\hline & Retired & 14 & 9,7 & 77,8 \\
\hline & Academician & 1 & 0,7 & 78,5 \\
\hline & Teacher & 2 & 1,4 & 79,9 \\
\hline & Banker & 1 & 0,7 & 80,6 \\
\hline & Doctor & 1 & 0,7 & 81,2 \\
\hline & Lawyer & 19 & 13,2 & 94,4 \\
\hline & Self employment & 8 & 5,6 & 100,0 \\
\hline & Director & 144 & 100,0 & \\
\hline & Police/ Soldier & 9 & 6,2 & 6,2 \\
\hline & TOTAL & 53 & 36,8 & 43,1 \\
\hline \multirow{7}{*}{ Education Level } & Primary School & 15 & 10,4 & 53,5 \\
\hline & High School & 58 & 40,3 & 93,8 \\
\hline & Associate & 8 & 5,6 & 99,3 \\
\hline & Undergraduate & 1 & 0,7 & 100,0 \\
\hline & Postgraduate & 144 & 100,0 & \\
\hline & Others (Phd etc.) & 1 & 0,7 & 0,7 \\
\hline & TOTAL & 25 & 17,4 & 18,1 \\
\hline \multirow{3}{*}{$\begin{array}{c}\text { Monthly Family } \\
\text { Income }\end{array}$} & 700 TL and down & 32 & 22,2 & 40,3 \\
\hline & $701-1000 \mathrm{TL}$ & 36 & 25,0 & 65,3 \\
\hline & $1001-1500 \mathrm{TL}$ & 33 & 22,9 & 88,2 \\
\hline
\end{tabular}




\begin{tabular}{|c|c|c|c|c|}
\hline \multirow{4}{*}{} & $1501-2000 \mathrm{TL}$ & 17 & 11,8 & 100,0 \\
\cline { 2 - 5 } & $2001-3000 \mathrm{TL}$ & 144 & 100,0 & \\
\cline { 2 - 5 } & $3001 \mathrm{TL}$ and above & 94 & 65,3 & 65,3 \\
\cline { 2 - 5 } & TOTAL & 50 & 34,7 & 100,0 \\
\hline
\end{tabular}

\section{Research Findings}

\subsection{Reliability and the Validity}

Based on the results revealed by factor analysis. The values for the film festival, the flower festival and the boyoz festival were found as significant in the level of $\mathrm{p}=0.00$. The Kaiser-Meyer-Olkin (KMO) sampling adequacy values were fixed as 0,78 for the film festival, 0,70 for the flower festival, and 0,71 for the boyoz festival. The explained variance ratio was 0,65 for the film festival, 0,60 for the flower festival and 0,57 for the boyoz festival. In other words, the dimensions of the participation motives of the visitors define the concepts which are contained for each of the festivals. Also the explained variance values adequacy levels in the subdimensions of the visitors' participation motives are among the adequate levels. As the Tavşancil (as cited by 2002:48; 2009:90) stated, in the social sciences, the variance ratios which vary between the range of $0,40-0,60$ are accepted as adequate.

According to the factor analysis results;

a) In the $12^{\text {th }}$ International İzmir Film Festival, the uniqueness relation, escaping, change, family, socialising dimensions

b) In the $15^{\text {th }}$ International Bayındır Flower Festival, the socialising, uniqueness relation, family, escaping and curiosity dimensions,

c) In the $1^{\text {st }}$ Izmir Boyoz Festival, the uniqueness interest, socialising, escape and family dimensions are revealed.

The findings of the factor analyses in Nicholson and Pearce's studies were as follows: In the "Malborough Wine, Food and Music Festival", thedimensions were socialising, details, escaping and family; in the "Hokitika Wildfoods Festival", the uniqueness, relation/change, entertainment/excitement/human, escaping and family in the "Wardbirds over Wanaka Festival", the uniqueness relation/change, socialising, details, escaping and family in the "New Zealand Golden Guitar Awards", the details/entertainment, escaping, variety, uniqueness relation and socialising were the figured out dimensions.

As the result of the reliability test applied to the scale, the Cronbach's alpha values are respectively 0,82 for the film festival, 0,77 for the flower festival and 0,78 for the boyoz festival. These values express the reliability of the applied scales for this research. For the analyses to give meaningful results, Nunnally (1967: 248) expressed that the obtained coefficient should be a value of 0,70 and over. Particularly in the social sciences, its being $70 \%$ is an acceptable value.

\subsection{The Participation Motive to the Events}

As it is mentioned in Table 4, five foremost items among the participation motivation statements are emphasized as per their event types. The statements of "I like films" and "I love flowers" are the most important among the participation motives to the events which are the special statements for the film festival and the flower festival. However, the statement of "I participate in the festival for to eat boyoz" which is peculiar to the boyoz festival, does not take place in the grading. The statements of "I love to see different things and to do different things" and "I like special events/festivals" are statements which have an importance for the three festivals. While the statements such as "Festivals are enlightening/exciting" have an importance for the participation in the film festival and the flower, they do not take place in the grading. While the visitors who are interested in the events participate in the flower festival, they participate in the boyoz festival for friends and entertainment. 
Table 4: Five Foremost Motives As Per The Event Type

\begin{tabular}{|c|c|c|}
\hline Motives & Average & $\begin{array}{l}\text { Standard } \\
\text { Deviation }\end{array}$ \\
\hline \multicolumn{3}{|l|}{ 12. International Izmir Film Festival } \\
\hline I like films & 4,69 & 0,59 \\
\hline I love to see different things and to do different things. & 4,41 & 0,76 \\
\hline I like special events/festivals & 4,39 & 0,63 \\
\hline I am curious & 4,38 & 0,69 \\
\hline The festivals are enlightening/exciting & 4,28 & 0,74 \\
\hline \multicolumn{3}{|l|}{ 15. International Bayındır Flower Festival } \\
\hline I like flowers & 4,86 & 0,43 \\
\hline I love to see different things and to do different things & 4,48 & 0,65 \\
\hline I like special events/festivals. & 4,39 & 0,70 \\
\hline I participate in for to gain experience from new and different things. & 4,24 & 0,73 \\
\hline The festivals are enlightening/exciting & 4,21 & 0,88 \\
\hline \multicolumn{3}{|l|}{ 1. İmir Boyoz Festival } \\
\hline I love to see different things and to do different things. & 4,47 & 0,64 \\
\hline I participate in to accompany my friends. & 4,28 & 1,01 \\
\hline I like special events/festivals & 4,26 & 0,85 \\
\hline I participate in to see entertainment & 4,25 & 0,92 \\
\hline I participate in to go with entertaining people. & 4,20 & 0,90 \\
\hline
\end{tabular}

Based on Table 4, the visitors generally do not participate in three festivals with the motives of entertaining the family, spending time with the family, to examine people and to join in the special interest groups. The other statements constitute the majority of the participation motives. According to the percentages, while the ones who like the films participate in the film festival, the ones who love flowers participate in the flower festival, the ratio of the ones who come to the boyoz festival, constitute a small part of the participations.

Within the scope of the research, there are three types of festivals as the film festival, the flower festival and the boyoz festival. The $\mathrm{t}$ and $\mathrm{F}$ tests were done for to analyse the hypotheses which are constituted by the scope of the research question. The data concerning the $t$ test that has been made for to test the $\mathrm{H}_{1}$ hypothesis oriented towards the genders of the visitors are included in the Table 5; 
Table 5. The Participation Motives To The Event As Per The Genders of The Participants

\begin{tabular}{|c|c|c|c|c|c|c|c|}
\hline & Dimensions & Gender & $n$ & $X$ & ss & $t$ & $p$ \\
\hline \multirow{10}{*}{ Film Festival } & \multirow{2}{*}{$\begin{array}{l}\text { Uniqueness } \\
\text { relation }\end{array}$} & Female & 96 & 4,3464 & 0,54455 & \multirow{2}{*}{1,508} & \multirow{2}{*}{0,133} \\
\hline & & Male & 79 & 4,2089 & 0,66196 & & \\
\hline & \multirow{2}{*}{ Escaping } & Female & 96 & 2,9818 & 0,96603 & \multirow{2}{*}{1,274} & \multirow{2}{*}{0,204} \\
\hline & & Male & 79 & 2,7848 & 1,07695 & & \\
\hline & \multirow{2}{*}{ Change } & Female & 96 & 3,9583 & 0,59889 & \multirow{2}{*}{1,411} & \multirow{2}{*}{0,16} \\
\hline & & Male & 79 & 3,8127 & 0,76684 & & \\
\hline & \multirow{2}{*}{ Family } & Female & 96 & 2,1979 & 1,02977 & \multirow{2}{*}{$-0,373$} & \multirow{2}{*}{0,71} \\
\hline & & Male & 79 & 2,2658 & 1,32005 & & \\
\hline & \multirow{2}{*}{ Socializing } & Female & 96 & 2,8021 & 0,80143 & \multirow{2}{*}{$-0,422$} & \multirow{2}{*}{0,674} \\
\hline & & Male & 79 & 2,8565 & 0,90532 & & \\
\hline \multirow{10}{*}{$\begin{array}{l}\text { Flower } \\
\text { Festival }\end{array}$} & \multirow{2}{*}{ Socializing } & Female & 87 & 4,0230 & 0,64802 & \multirow{2}{*}{2,728} & \multirow{2}{*}{0,007} \\
\hline & & Male & 54 & 3,7259 & 0,59596 & & \\
\hline & \multirow{2}{*}{$\begin{array}{l}\text { Uniqueness } \\
\text { relation }\end{array}$} & Female & 87 & 4,1858 & 0,63664 & \multirow{2}{*}{$-0,095$} & \multirow{2}{*}{0,925} \\
\hline & & Male & 54 & 4,1944 & 0,44362 & & \\
\hline & \multirow{2}{*}{ Family } & Female & 87 & 2,8908 & 1,18965 & \multirow{2}{*}{$-0,49$} & \multirow{2}{*}{0,625} \\
\hline & & Male & 54 & 2,9907 & 1,15534 & & \\
\hline & \multirow{2}{*}{ Escaping } & Female & 87 & 3,0517 & 1,13618 & \multirow{2}{*}{$-0,558$} & \multirow{2}{*}{0,578} \\
\hline & & Male & 54 & 3,1574 & 1,02250 & & \\
\hline & \multirow{2}{*}{ Curiosity } & Female & 87 & 3,0690 & 1,09749 & \multirow{2}{*}{0,026} & \\
\hline & & Male & 54 & 3,0648 & 0,77122 & & 0,919 \\
\hline & Uniqueness & Female & 94 & 4,0567 & 0,56350 & 2808 & 0005 \\
\hline & relation & Male & 50 & 3,6700 & 0,84950 & $2,0>0$ & 0,000 \\
\hline & Secializino & Female & 94 & 4,0213 & 0,55742 & 1860 & 0064 \\
\hline Boyoz & & Male & 50 & 3,8114 & 0,77628 & 1,00 & יד \\
\hline Festival & Escaping & Female & 94 & 3,2872 & 1,16664 & 1383 & 0160 \\
\hline & & Male & 50 & 3,0133 & 1,06044 & (1, & 0,10 \\
\hline & & Female & 94 & 2,2128 & 1,30031 & 0146 & 0656 \\
\hline & 1 animy & Male & 50 & 2,1100 & 1,34881 & ט & 0,000 \\
\hline
\end{tabular}

In the researches of Snipes and Ingram (2007:71), Thompson and Schofield (2009) and Yuan et. al. (2005:52), it is stated that the motive of participating in an event, reveals differentiation as per the genders of the visitors.

According to the findings which are included in the Table 5, there is no significant difference between the participation reasons in the dimensions of the uniqueness relation, escaping, change, family and socializing in the level of 0.05 level. There is no significant difference between the genders of the visitors and dimensions of the participation reasons to the film festival.

There is no significant difference between the genders of the visitors that participate in the flower festival and the socializing dimension, one of the reasons of their participation in the event. This result can be explained by the women' wish to be in a social environment in the flower festival. According to another finding in the table, the dimension of the uniqueness relation, one of the reasons of participation in the boyoz festival, the $p$ value of the $t$ test does not reveal any significant difference in the level of 0.05 level. There is no significant difference between the gender of the visitors and the dimension of the uniqueness relation, one of the causes of the participation in the boyoz festival. This result can be interpreted as the wish for participating in the event, as the boyoz festival has not been realized before and for this reason, want to participate in the event with the effect of the thought that this festival is the only festival. 
The data concerning the $\mathrm{F}$ test which is made for testing the $\mathrm{H}_{2}$ hypothesis oriented toward the ages of the visitors, is included in the Table 6;

Table 6: The Participation Motives To The Event As Per The Ages Of The Participants

\begin{tabular}{|c|c|c|c|c|c|c|c|}
\hline & Dimensions & & $K t$ & $S d$ & Ko & $F$ & $p$ \\
\hline \multirow{15}{*}{ Film Festival } & \multirow{3}{*}{$\begin{array}{l}\text { Uniqueness } \\
\text { relation }\end{array}$} & Intergroup & 1,005 & 5 & 0,201 & \multirow{3}{*}{0,547} & \multirow{3}{*}{0,741} \\
\hline & & In-group & 62,164 & 169 & 0,368 & & \\
\hline & & Total & 63,169 & 174 & & & \\
\hline & \multirow{3}{*}{ Escaping } & Intergroup & 5,674 & 5 & 1,135 & \multirow{3}{*}{1,095} & \multirow{3}{*}{0,365} \\
\hline & & In-group & 175,129 & 169 & 1,036 & & \\
\hline & & Total & 180,804 & 174 & & & \\
\hline & \multirow{3}{*}{ Change } & Intergroup & 1,861 & 5 & 0,372 & \multirow{3}{*}{0,796} & \multirow{3}{*}{0,55} \\
\hline & & In-group & 79,000 & 169 & 0,467 & & \\
\hline & & Total & 80,860 & 174 & & & \\
\hline & \multirow{3}{*}{ Family } & Intergroup & 32,791 & 5 & 6,558 & \multirow{3}{*}{5,431} & \multirow{3}{*}{0,000} \\
\hline & & In-group & 204,066 & 169 & 1,207 & & \\
\hline & & Total & 236,857 & 174 & & & \\
\hline & \multirow{3}{*}{ Socializing } & Intergroup & 2,119 & 5 & 0,424 & \multirow{3}{*}{0,582} & \multirow{3}{*}{0,713} \\
\hline & & In-group & 122,957 & 169 & 0,728 & & \\
\hline & & Total & 125,076 & 174 & & & \\
\hline \multirow{15}{*}{$\begin{array}{l}\text { Flower } \\
\text { Festival }\end{array}$} & \multirow{3}{*}{ Socializing } & Intergroup & 0,688 & 6 & 0,115 & \multirow{3}{*}{0,269} & \multirow{3}{*}{0,951} \\
\hline & & In-group & 57,190 & 134 & 0,427 & & \\
\hline & & Total & 57,878 & 140 & & & \\
\hline & \multirow{3}{*}{$\begin{array}{l}\text { Uniqueness } \\
\text { relation }\end{array}$} & Intergroup & 1,505 & 6 & 0,251 & \multirow{3}{*}{0,768} & \multirow{3}{*}{0,597} \\
\hline & & In-group & 43,785 & 134 & 0,327 & & \\
\hline & & Total & 45,290 & 140 & & & \\
\hline & \multirow{3}{*}{ Family } & Intergroup & 10,794 & 6 & 1,799 & \multirow{3}{*}{1,325} & \multirow{3}{*}{0,250} \\
\hline & & In-group & 181,997 & 134 & 1,358 & & \\
\hline & & Total & 192,791 & 140 & & & \\
\hline & \multirow{3}{*}{ Escaping } & Intergroup & 3,819 & 6 & 0,636 & \multirow{3}{*}{0,523} & \multirow{3}{*}{0,790} \\
\hline & & In-group & 162,983 & 134 & 1,216 & & \\
\hline & & Total & 166,801 & 140 & & & \\
\hline & \multirow{3}{*}{ Curiosity } & Intergroup & 7,860 & 6 & 1,310 & & \\
\hline & & In-group & 127,250 & 134 & 0,950 & 1,380 & 0,227 \\
\hline & & Total & 135,110 & 140 & & & \\
\hline
\end{tabular}




\begin{tabular}{|c|c|c|c|c|c|c|c|}
\hline \multirow{12}{*}{ Boyoz Festival } & \multirow{3}{*}{$\begin{array}{l}\text { Uniqueness } \\
\text { relation }\end{array}$} & Intergroup & 1,736 & 4 & 0,434 & \multirow{3}{*}{0,887} & \multirow{3}{*}{0,474} \\
\hline & & In-group & 68,037 & 139 & 0,489 & & \\
\hline & & Total & 69,773 & 143 & & & \\
\hline & \multirow{3}{*}{ Socializing } & Intergroup & 5,357 & 4 & 1,339 & \multirow{3}{*}{3,415} & \multirow{3}{*}{0,011} \\
\hline & & In-group & 54,505 & 139 & 0,392 & & \\
\hline & & Total & 59,862 & 143 & & & \\
\hline & \multirow{3}{*}{ Escaping } & Intergroup & 11,956 & 4 & 2,989 & \multirow{3}{*}{2,413} & \multirow{3}{*}{0,052} \\
\hline & & In-group & 172,173 & 139 & 1,239 & & \\
\hline & & Total & 184,129 & 143 & & & \\
\hline & \multirow{3}{*}{ Family } & Intergroup & 41,578 & 4 & 10,394 & \multirow{3}{*}{7,043} & \multirow{3}{*}{0,000} \\
\hline & & In-group & 205,157 & 139 & 1,476 & & \\
\hline & & Total & 246,734 & 143 & & & \\
\hline
\end{tabular}

According to the findings in Table 6, the reasons of participation in the film festival event such as Uniqueness relation, Escaping, Change and Socialising dimensions do not reveal any difference in the $\mathrm{p}$ value of the $\mathrm{F}$ test in the 0.05 level. There is a significant difference only in the family dimension. In other words, the ages of the visitors may effect the family dimension which is one of the participation reasons of the film festival. On the other hand, there is no significant difference between the ages of the visitors and the reasons of participation in the flower festival. According to another finding in the Table, the $\mathrm{p}$ value of the F test of the Socialising and family dimensions which are among the causes of participation in the boyoz festival reveal no significant difference in the 0.05 level. Park (2009:45), Snipes and Ingram (2007:71), Thompson and Schofield (2009) and Yuan et al. (2005:52) stated in their research that, the motives of the visitors to participate in an event, revealed difference according to their ages. While there was difference in the research of Snipes and Ingram (2007), in the "entertainment" dimension, in the research of Thompson ve Schofield (2009), in the "culture and sports" and "Socialising and local special event" dimensions, in the studies of the Yuan et al. (2005) the difference was revealed in the dimension of the "escaping".

In the research, no significant difference have been found between the ages of the visitors participate in the flower festival and the ages of the film festival participants as well as the boyoz festival participants are found significant in the "family" dimension. There is no significant difference between the ages of the visitors participate in the Boyoz festival and the "Socializing" dimension. Due to the increase of the participation in the young age group with the aim of socializing, it is thought that there is difference between the perception in the Socializing dimension.

An interpretation can also be made as the participants in the young age group may show interest to the events for Socializing.

The data concerning the $\mathrm{F}$ test which is made for testing the hypothesis oriented towards the family structure of the visitors is included in the Table 7; 
Gunlu, E., Lale, C. / Journal of Yasar University, 2015, 10/40, 6730-6751

Table 7. The Participation Motive Of The Participants To the Event As Per Their Family Structures

\begin{tabular}{|c|c|c|c|c|c|c|c|}
\hline \multirow{16}{*}{$\begin{array}{l}\text { Film } \\
\text { Festival }\end{array}$} & Dimensions & & $K t$ & $S d$ & Ko & $F$ & $p$ \\
\hline & \multirow{3}{*}{$\begin{array}{l}\text { Uniqueness } \\
\text { relation }\end{array}$} & Intergroup & 1,146 & 4 & 0,287 & \multirow{3}{*}{0,785} & \multirow{3}{*}{0,536} \\
\hline & & In-group & 62,023 & 170 & 0,365 & & \\
\hline & & Total & 63,169 & 174 & & & \\
\hline & \multirow{3}{*}{ Escape } & Intergroup & 4,442 & 4 & 1,111 & \multirow{3}{*}{1,071} & \multirow{3}{*}{0,373} \\
\hline & & In-group & 176,361 & 170 & 1,037 & & \\
\hline & & Total & 180,804 & 174 & & & \\
\hline & \multirow{3}{*}{ Change } & Intergroup & 1,283 & 4 & 0,321 & \multirow{3}{*}{0,685} & \multirow{3}{*}{0,603} \\
\hline & & In-group & 79,578 & 170 & 0,468 & & \\
\hline & & Total & 80,860 & 174 & & & \\
\hline & \multirow{3}{*}{ Family } & Intergroup & 18,176 & 4 & 4,544 & \multirow{3}{*}{3,532} & \multirow{3}{*}{0,008} \\
\hline & & In-group & 218,682 & 170 & 1,286 & & \\
\hline & & Total & 236,857 & 174 & & & \\
\hline & \multirow{3}{*}{ Socializing } & Intergroup & 1,958 & 4 & 0,489 & \multirow{3}{*}{0,676} & \multirow{3}{*}{0,610} \\
\hline & & In-group & 123,118 & 170 & 0,724 & & \\
\hline & & Total & 125,076 & 174 & & & \\
\hline \multirow{15}{*}{$\begin{array}{l}\text { Flower } \\
\text { Festival }\end{array}$} & \multirow{3}{*}{ Socializing } & Intergroup & 1,236 & 4 & 0,309 & \multirow{3}{*}{0,742} & \multirow{3}{*}{0,565} \\
\hline & & In-group & 56,642 & 136 & 0,416 & & \\
\hline & & Total & 57,878 & 140 & & & \\
\hline & \multirow{3}{*}{$\begin{array}{l}\text { Uniqueness } \\
\text { relation }\end{array}$} & Intergroup & 1,618 & 4 & 0,404 & \multirow{3}{*}{1,259} & \multirow{3}{*}{0,289} \\
\hline & & In-group & 43,672 & 136 & 0,321 & & \\
\hline & & Total & 45,290 & 140 & & & \\
\hline & \multirow{3}{*}{ Family } & Intergroup & 2,510 & 4 & 0,628 & \multirow{3}{*}{0,449} & \multirow{3}{*}{0,773} \\
\hline & & In-group & 190,280 & 136 & 1,399 & & \\
\hline & & Total & 192,791 & 140 & & & \\
\hline & & Intergroup & 2,977 & 4 & 0,744 & & \\
\hline & Escaping & In-group & 163,824 & 136 & 1,205 & 0,618 & 0,651 \\
\hline & & Total & 166,801 & 140 & & & \\
\hline & & Intergroup & 4,418 & 4 & 1,104 & & \\
\hline & Curiosity & In-group & 130,692 & 136 & 0,961 & 1,149 & 0,336 \\
\hline & & Total & 135,110 & 140 & & & \\
\hline & & Intergroup & 3,544 & 5 & 0,709 & & \\
\hline & $\begin{array}{l}\text { Uniqueness } \\
\text { relation }\end{array}$ & In-group & 66,229 & 138 & 0,480 & 1,477 & 0,201 \\
\hline & & Total & 69,773 & 143 & & & \\
\hline $\begin{array}{l}\text { Boyoz } \\
\text { Festival }\end{array}$ & & Intergroup & 1,911 & 5 & 0,382 & & \\
\hline & Socializing & In-group & 57,950 & 138 & 0,420 & 0,910 & 0,476 \\
\hline & & Total & 59,862 & 143 & & & \\
\hline & Escape & Intergroup & 5,507 & 5 & 1,101 & 0,851 & 0,516 \\
\hline
\end{tabular}




\begin{tabular}{|l|l|l|l|l|l|l|l|}
\hline & In-group & 178,622 & 138 & 1,294 & \multirow{2}{*}{} & \\
\cline { 3 - 6 } & Total & 184,129 & 143 & & & \multirow{3}{*}{6,830} & \multirow{2}{*}{0,000} \\
\cline { 2 - 6 } & \multirow{3}{*}{ Family } & Intergroup & 48,945 & 5 & 9,789 & \\
\cline { 2 - 6 } & In-group & 197,789 & 138 & 1,433 & & \\
\cline { 2 - 5 } & Total & 246,734 & 143 & & & \\
\hline
\end{tabular}

According to the findings which are included in the Table 7, there is no significant difference in the family dimension of the causes of participation in the film festival. The family structure of the visitors may affect the family dimension as a cause of participation in the film festival. An interpretation can be made as the ones whose family type is married, may wish to participate in the events for to entertain with their families and spend time. There is no significant difference between the family structure of the visitors and the the dimensions of the participation causes in the flower festival. According to another finding in the table, $p$ value of the $F$ test in the family dimension which is one of the causes of participation in the boyoz festival, in the 0.05 level. There is no significant difference between the family structure of the visitors and the family dimension which is one of the causes of participating in the boyoz festival. This result is a sign that the family structure can affect the motives of the visitors whose participation cause is family.

Yuan et al. (2005:52), in their researches, stated that the visitors who participated in the events in the "family" dimension, which was one of the participation motives of the visitors, revealed differentiation as per the family structure of the visitors.

The data concerning the $\mathrm{F}$ test which has been made for testing the $\mathrm{H}_{4}$ hypothesis oriented toward the education level of the visitors are presented in Table 8;

Table 8. The Participation Motives of the Participants To The Event As Per Their Education Level

\begin{tabular}{|c|c|c|c|c|c|c|c|}
\hline & Dimensions & & $K t$ & $S d$ & Ko & $F$ & $p$ \\
\hline \multirow{15}{*}{ Film Festival } & \multirow{3}{*}{$\begin{array}{l}\text { Uniqueness } \\
\text { relation }\end{array}$} & Intergroup & 2,503 & 5 & 0,501 & \multirow{3}{*}{1,395} & \multirow{3}{*}{0,229} \\
\hline & & In-group & 60,666 & 169 & 0,359 & & \\
\hline & & Total & 63,169 & 174 & & & \\
\hline & \multirow{3}{*}{ Escape } & Intergroup & 5,911 & 5 & 1,182 & \multirow{3}{*}{1,142} & \multirow{3}{*}{0,340} \\
\hline & & In-group & 174,892 & 169 & 1,035 & & \\
\hline & & Total & 180,804 & 174 & & & \\
\hline & \multirow{3}{*}{ Change } & Intergroup & 0,947 & 5 & 0,189 & \multirow{3}{*}{0,400} & \multirow{3}{*}{0,848} \\
\hline & & In-group & 79,914 & 169 & 0,473 & & \\
\hline & & Total & 80,860 & 174 & & & \\
\hline & \multirow{3}{*}{ Family } & Intergroup & 20,464 & 5 & 4,093 & \multirow{3}{*}{3,196} & \multirow{3}{*}{0,009} \\
\hline & & In-group & 216,393 & 169 & 1,280 & & \\
\hline & & Total & 236,857 & 174 & & & \\
\hline & \multirow{3}{*}{ Socializing } & Intergroup & 6,377 & 5 & 1,275 & \multirow{3}{*}{1,816} & \multirow{3}{*}{0,112} \\
\hline & & In-group & 118,699 & 169 & 0,702 & & \\
\hline & & Total & 125,076 & 174 & & & \\
\hline \multirow{8}{*}{ Flower Festival } & \multirow{3}{*}{ Socializing } & Intergroup & 8,511 & 5 & 1,702 & \multirow{3}{*}{4,655} & \multirow{3}{*}{0,001} \\
\hline & & In-group & 49,367 & 135 & 0,366 & & \\
\hline & & Total & 57,878 & 140 & & & \\
\hline & \multirow{3}{*}{$\begin{array}{l}\text { Uniqueness } \\
\text { relation }\end{array}$} & Intergroup & 2,335 & 5 & 0,467 & \multirow{3}{*}{1,467} & \multirow{3}{*}{0,205} \\
\hline & & In-group & 42,955 & 135 & 0,318 & & \\
\hline & & Total & 45,290 & 140 & & & \\
\hline & \multirow{2}{*}{ Family } & Intergroup & 4,661 & 5 & 0,932 & \multirow{2}{*}{0,669} & \multirow{2}{*}{0,648} \\
\hline & & In-group & 188,129 & 135 & 1,394 & & \\
\hline
\end{tabular}


Gunlu, E., Lale, C. / Journal of Yasar University, 2015, 10/40, 6730-6751

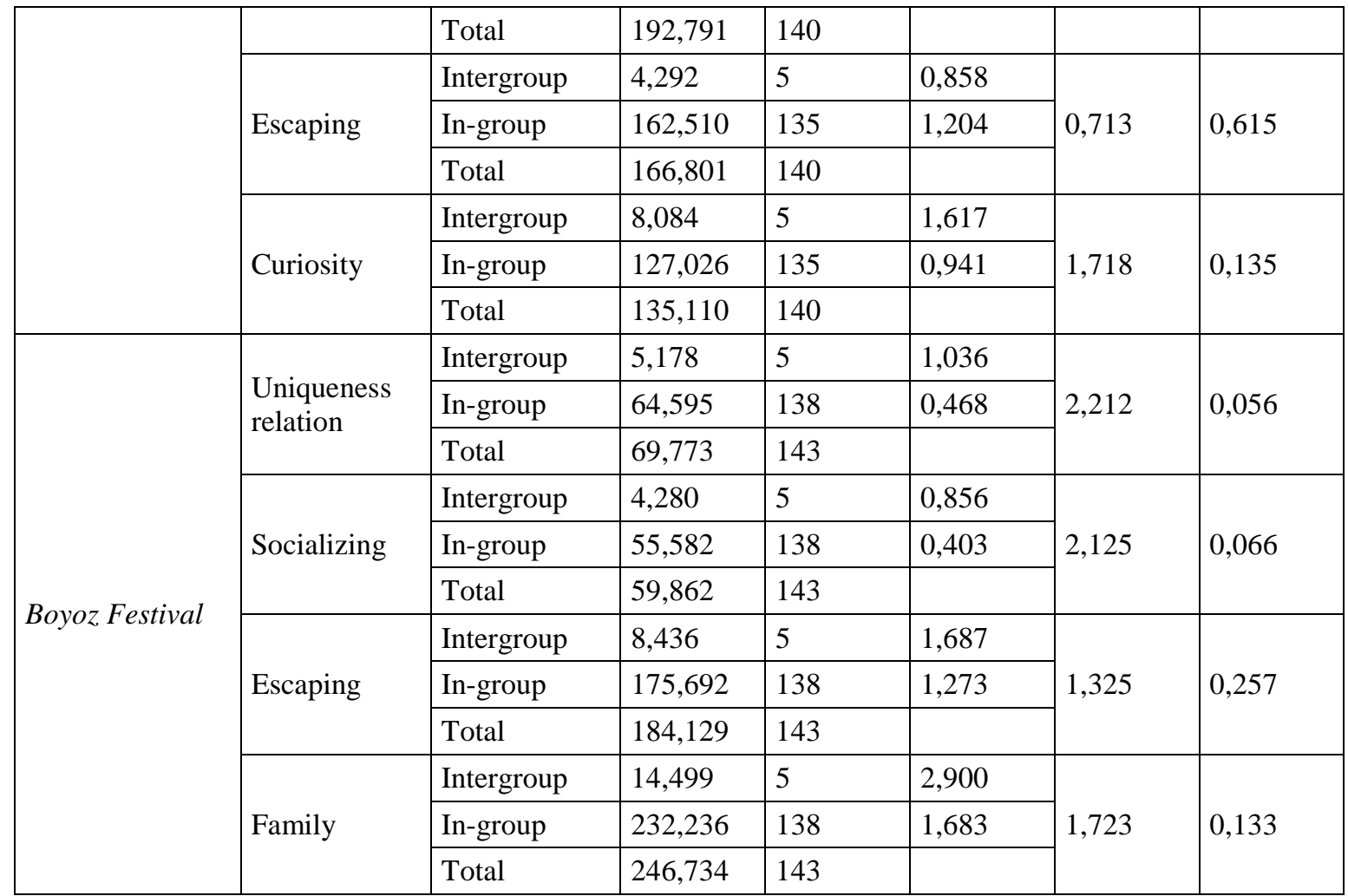

According to the findings in Table 8, the participation causes to the film festival event reveal a significant difference only in the family dimension. In other words, the education level of the visitors may affect the family dimension which is one of the causes of participation in the film festival. This result can be interpreted as the visitors' being students in general, who have a two-year, bachelor and post graduate degrees, they do not prefer to spend time with their families. According to another finding in the table, the $\mathrm{p}$ value of the F test of the Socializing dimension, one of the participation cause of participating in the flower festival, reveal a significant difference in the level of 0.05 level. There is no significant difference between the education level of the visitor and the the Socializing dimension which is one of the causes of participation in the flower festival. This result is a sign that the education level can affect the motives of the visitors whose cause of participating in the event, is the socializing.

There is no significant difference between the education level and the dimensions of the participation causes of participation in the boyoz festival. This result shows that the education level does not affect the causes of participation in the boyoz festival event.

While Snipes ve Ingram (2007:71), in their research stated that the "entertainment" dimension, Yuan et al.(2005:52) in their research stated that the "Socializing" and "escape" dimensions revealed difference as per the education level of the visitors who participated in the event.

The data concerning the $\mathrm{F}$ test which is made for testing the $\mathrm{H}_{5}$ hypothesis oriented toward the monthly income of the visitors are presented in Table 9.; 
Gunlu, E., Lale, C. / Journal of Yasar University, 2015, 10/40, 6730-6751

Table 9. The Participation Motives To The Event As Per The Income Level Of The Participants

\begin{tabular}{|c|c|c|c|c|c|c|c|}
\hline & Dimensions & & $K t$ & $S d$ & Ko & $F$ & $p$ \\
\hline \multirow{15}{*}{ Film Festival } & \multirow{3}{*}{$\begin{array}{l}\text { Uniqueness } \\
\text { relation }\end{array}$} & Intergroup & 1,784 & 5 & 0,357 & \multirow{3}{*}{0,982} & \multirow{3}{*}{0,430} \\
\hline & & In-group & 61,385 & 169 & 0,363 & & \\
\hline & & Total & 63,169 & 174 & & & \\
\hline & \multirow{3}{*}{ Escaping } & Intergroup & 1,563 & 5 & 0,313 & \multirow{3}{*}{0,295} & \multirow{3}{*}{0,915} \\
\hline & & In-group & 179,241 & 169 & 1,061 & & \\
\hline & & Total & 180,804 & 174 & & & \\
\hline & \multirow{3}{*}{ Change } & Intergroup & 3,091 & 5 & 0,618 & \multirow{3}{*}{1,344} & \multirow{3}{*}{0,248} \\
\hline & & In-group & 77,769 & 169 & 0,460 & & \\
\hline & & Total & 80,860 & 174 & & & \\
\hline & \multirow{3}{*}{ Family } & Intergroup & 14,744 & 5 & 2,949 & \multirow{3}{*}{2,244} & \multirow{3}{*}{0,052} \\
\hline & & In-group & 222,113 & 169 & 1,314 & & \\
\hline & & Total & 236,857 & 174 & & & \\
\hline & \multirow{3}{*}{ Socializing } & Intergroup & 4,695 & 5 & 0,939 & \multirow{3}{*}{1,318} & \multirow{3}{*}{0,259} \\
\hline & & In-group & 120,380 & 169 & 0,712 & & \\
\hline & & Total & 125,076 & 174 & & & \\
\hline \multirow{15}{*}{$\begin{array}{l}\text { Flower } \\
\text { Festival }\end{array}$} & \multirow{3}{*}{ Socializing } & Intergroup & 2,682 & 5 & 0,536 & \multirow{3}{*}{1,312} & \multirow{3}{*}{0,263} \\
\hline & & In-group & 55,196 & 135 & 0,409 & & \\
\hline & & Total & 57,878 & 140 & & & \\
\hline & \multirow{3}{*}{$\begin{array}{l}\text { Uniqueness } \\
\text { relation }\end{array}$} & Intergroup & 1,142 & 5 & 0,228 & \multirow{3}{*}{0,698} & \multirow{3}{*}{0,626} \\
\hline & & In-group & 44,148 & 135 & 0,327 & & \\
\hline & & Total & 45,290 & 140 & & & \\
\hline & \multirow{3}{*}{ Family } & Intergroup & 4,047 & 5 & 0,809 & & \\
\hline & & In-group & 188,744 & 135 & 1,398 & 0,579 & 0,716 \\
\hline & & Total & 192,791 & 140 & & & \\
\hline & & Intergroup & 10,978 & 5 & 2,196 & & \\
\hline & Escaping & In-group & 155,823 & 135 & 1,154 & 1,902 & 0,098 \\
\hline & & Total & 166,801 & 140 & & & \\
\hline & & Intergroup & 4,538 & 5 & 0,908 & & \\
\hline & Curiosity & In-group & 130,572 & 135 & 0,967 & 0,938 & 0,458 \\
\hline & & Total & 135,110 & 140 & & & \\
\hline & & Intergroup & 0,468 & 5 & 0,094 & & \\
\hline & $\begin{array}{l}\text { Uniqueness } \\
\text { relation }\end{array}$ & In-group & 69,305 & 138 & 0,502 & 0,186 & 0,967 \\
\hline & & Total & 69,773 & 143 & & & \\
\hline & & Intergroup & 3,282 & 5 & 0,656 & & \\
\hline & Socializing & In-group & 56,579 & 138 & 0,410 & 1,601 & 0,164 \\
\hline Boyoz & & Total & 59,862 & 143 & & & \\
\hline Festival & & Intergroup & 3,207 & 5 & 0,641 & & \\
\hline & Escaping & In-group & 180,922 & 138 & 1,311 & 0,489 & 0,784 \\
\hline & & Total & 184,129 & 143 & & & \\
\hline & & Intergroup & 6,221 & 5 & 1,244 & & \\
\hline & Family & In-group & 240,514 & 138 & 1,743 & 0,714 & 0,614 \\
\hline & & Total & 246,734 & 143 & & & \\
\hline
\end{tabular}


According to the above included findings, as there is no significant difference between the monthly family income of the visitors and the dimensions of the causes of participation in the film festival, there is also no significant difference between the family income and the causes of participation in the flower festival. Also for the boyoz festival, the case does not reveal any differentiation .

However, Yuan et al. (2005:52-53), in their researches, stated that the dimensions of the "escaping" and "wine" revealed difference as per the monthly family income of the visitors who participated in the event.

By analysing the obtained data, the evaluation concerning the testing of the hypotheses as per the event types, is shown in the below included Table 10.

Table 10. The Evaluation Concerning The Testing of The Hypotheses

\begin{tabular}{|c|c|c|c|}
\hline & Film Festival & Flower Festival & Boyoz Festival \\
\hline $\begin{array}{l}\text { Hypothesis } 1 \text { : } \\
\text { The participation motives reveal } \\
\text { difference as per the gender of } \\
\text { the visitors. }\end{array}$ & REFUSE & ACCEPT & ACCEPT \\
\hline $\begin{array}{l}\text { Hypothesis } 2 \text { : } \\
\text { The participation motives of the } \\
\text { visitors reveal difference as per } \\
\text { their genders. }\end{array}$ & ACCEPT & REFUSE & ACCEPT \\
\hline $\begin{array}{l}\text { Hipotez } 3 \text { : } \\
\text { The participation motives of the } \\
\text { visitors to the event reveal } \\
\text { difference as per their family } \\
\text { structure. }\end{array}$ & ACCEPT & REFUSE & ACCEPT \\
\hline $\begin{array}{l}\text { Hypothesis 4: } \\
\text { The participation motives of the } \\
\text { visitors reveal difference as per } \\
\text { their education level. }\end{array}$ & ACCEPT & ACCEPT & REFUSE \\
\hline $\begin{array}{l}\text { Hypothesis 5: } \\
\text { The participation motives of the } \\
\text { visitors reveal difference as per } \\
\text { their income level. }\end{array}$ & REFUSE & REFUSE & REFUSE \\
\hline
\end{tabular}

\subsection{The Visitor Profile As Per the Event Type}

According to the research results, when the three types of event, the film festival, the flower festival and the boyoz festival is compared, it is seen that there are a number of differences and similarities between the visitors according to the event type. The mentioned features are seen in the visitor profile which is formed in the Table 11. 
Table 11. The Visitor Profile As Per The Event Type

\begin{tabular}{|c|c|c|c|}
\hline & $\begin{array}{l}\text { 12. International Izmir } \\
\text { Film Festival }\end{array}$ & $\begin{array}{c}\text { 15. International } \\
\text { Bayındir Flower } \\
\text { Festival }\end{array}$ & 1.Izmir Boyoz Festival \\
\hline Gender & Female & Female & Female \\
\hline Age & $18-34$ & $45-64$ & $18-24$ \\
\hline Family Type & Single & $\begin{array}{l}\text { Married and has a } \\
\text { child }\end{array}$ & Single \\
\hline Social Status & Student & $\begin{array}{l}\text { Retired or House- } \\
\text { Wife }\end{array}$ & Student \\
\hline $\begin{array}{c}\text { Education } \\
\text { Level }\end{array}$ & Undergraduate & Primary School & High School or Undergraduate \\
\hline $\begin{array}{l}\text { Monthly } \\
\text { Family } \\
\text { Income }\end{array}$ & 2001 TL and over & $701 \mathrm{TL}-1000 \mathrm{TL}$ & $1001 \mathrm{TL}-3000 \mathrm{TL}$ \\
\hline $\begin{array}{l}\text { Motives Of } \\
\text { Participation } \\
\text { in An Event }\end{array}$ & $\begin{array}{l}\text { Liking Films, loving } \\
\text { events, interested in the } \\
\text { events,loving to see } \\
\text { different things and } \\
\text { doing different things. }\end{array}$ & $\begin{array}{l}\text { Loving flowers, } \\
\text { loving events, } \\
\text { loving to see } \\
\text { different things and } \\
\text { doing different } \\
\text { things, to gain } \\
\text { experience. }\end{array}$ & $\begin{array}{l}\text { Loving events, loving to see } \\
\text { different things and to do } \\
\text { different things, to accompany } \\
\text { friends, to watch entertainment } \\
\text { and be together with } \\
\text { entertaining people. }\end{array}$ \\
\hline
\end{tabular}

\section{Conclusion and Discussion}

Based on literature review, it is find out that many researches refer to the importance of the visitor motives in the management of the event (Backman et. al., 1995; Chang, 2006, 2011; Crompton and Mackay, 1997; Formica and Uysal, 1996, 1998; Lee, 2000; Lee et. al., 2004; Mc Morland and Mac Taggart, 2008; Mohr et al., 1993, Park et al., 2008; Schneider and Backman, 1996; Scott, 1996; Uysal et al., 1993). While in the international literature, there are some studies which reveal that the motives can differentiate as per the events, in the national literature, it is striking that there is a gap in this subject. This research is designed to fulfill the mentioned gap. Within this context, the motives of the individuals that participate in the events in Izmir, are analysed as per the event type, comparisons are made between the motives and the event types.

According to the factor analyses, in the12th International Izmir Film Festival, the uniqueness relation, escaping, change, family and socializing; in the 15th International Bayındir Flower Festival, the socializing, uniqueness relation, family, escaping and curiosity; in the 1st Izmir Boyoz Festival, the uniqueness relation, socializing, escaping and family dimensions appeared. In the Nicholson and Pearce's studies, the dimensions which appeared in the "Malborough Wine, Food and Music Festival " and the dimensions which revealed in the 1. "Izmir Boyoz Festival", show similarity though there is a difference in the grading. The revelation of the entertainment/excitement/human dimension in another event concerning the food, the "Hokitika Wildfoods Festival", is different from the boyoz festival, which can be interpreted as the food theme of the event which is wildfood concerning some animals such as worm, insect etc... is not a welcomed issue for Turkish Food Culture and citizens.

In the Nicholson and Pearce's studies, though the dimensions revealed in the "New Zealand Golden Guitar Awards" which is concerned with a cultural event, and the dimensions occur in the " $12^{\text {th }}$ International Izmir Film Festival" which is evaluated in the scope of the Izmir city show similarity, the entertainment/details and the diversity dimension in the "Golden Guitar Awards" revealed as a dimension different form the film festival. This difference also shows the entertainment dimension by the organised concerts, the seminars and the shows organised except for the awards.

In Nicholson and Pearce's study, the dimensions revealed in the "Warbirds over Wanaka" which is an event concerning the special hobbies and the dimensions revealed in the "15 $5^{\text {th }}$ International Bayındir Flower Festival" which is examined in the scope of the Izmir city, show similarity, as well. The only difference is sourced from the revelation of the dimension of the details in the "Warbirds over Wanaka" while the revelation of the 
curiosity dimension in the flower festival. This result can be interpreted as, in the theme of the "Warbirds over Wanaka", the existence of the difference air vehicles which carry the features concerning the flight cause the revelation of the details dimension concerning the event.

In the research of the Uysal et al. (1993), one of the studies about the events concerning the food, escaping, excitement, change, socializing and family togetherness are occurring, in Yuan et al. (2005) studies, escaping, wine, socializing and family togetherness dimensions revealed. In the studies of Park et al. (2008), the dimensions of tasting new wine and food, liking event, raising the social status, escaping from the routine life, meeting new people, spending time with the family, meeting the celebrities and wine experts; in Chang (2011) studies, wine, escaping/event change, food, known group socializing, external sociability, art dimension revealed. The Ralston and Crompton(1988) which studied the cultural event set forth the dimensions of the family togetherness, meeting new people and observing people, nostalgia, learning and discovering, social links, search for doing something, escaping from personal and social pressures. In the study that the Formica and Uysal (1996) made, the dimensions of the excitement/pleasure, socializing, entertainment, new events, family togetherness revealed. And Lee, Lee and Wicks (2004) set forth the cultural discovery, family togethers, change, escaping and the attraction of an event and socializing dimensions. In the study which Mohr et al. (1993) made, who dealt with the event concerning the special hobbies, the dimensions of socializing, family togetherness, excitement/extraordinary, escaping, new events were revealed.

When the results of the hypotheses revealed in the study are compared with the results of the hypotheses which are included in the literature collection; Snipes and Ingram (2007:71), Thompson and Schofield (2009) and Yuan et al. (2005:52), in their researches, stated that the motive of the participation in an event revealed difference as per the genders of the visitors. While Snipes and Ingram (2007) in their research, the "escape" and "entertainment" dimensions were revealing difference, in the studies of Yuan et al. (2005), the dimensions of "escaping" and "wine" revealed difference. In the research done within the city of Izmir, a significant difference was found between the genders of the visitors participate in the boyoz festival and the "uniqueness relation" dimension. The reason for this is the perceptions of women to the socializing and uniqueness relation. However, there is no significant difference between the genders of the visitors which participate in the film festival and the motives of their participation in the event.

Park (2009:45), Snipes and Ingram (2007:71), Thompson and Schofield (2009) and Yuan et al. (2005:52) stated in their researches that the motives of their participation in the event revealed difference as per the ages of the visitors. Snipes Ingram (2007) in their research, the "entertainment" dimension, Thompson and Schofield (2009) in their research, the "culture" and "sport" and the "socializing and the local special event" dimensions were revealing difference, but in the studies of Yuan et al. (2005) there is difference in the "escaping" dimension. In this research, while there is no significant difference between the ages of the visitors that participate in the flower festival and motives of participation in the event, there is a significant difference between the ages of the film festival participants and the boyoz festival participants. Also there is no significant difference between the ages of the visitors and the dimension of socializing. The increase in the young age group with the aim of socializing, for this reason, there is thought to be a difference between the perceptions in the socializing dimensions.

In Yuan et al (2005:52) in his researches, the "family" dimension, one of the visitors" motives of participation in an event as per the family type of the visitors participating in an event, revealed difference. There is no significant difference between the family type of the visitors who participate in the film festival and the family type of the visitors participating in the boyoz festival and the "family" dimension. It can be interpreted that the ones whose family type are married may wish to participate in the events with the aim of enjoying together with their families and spend time. There is no significant difference between the family type of the visitor participating in the flower festival and the motives of their participating in the event.

While Snipes and Ingram (2007:71), in their researches, stated that the "entertainment" dimension , Yuan et al. (2005:52) stated in their research that the dimensions of the "socializing" and "escape" were revealing difference as per the education level of the visitors participated in the event. Whereas in this research, there is a significant difference between the education level of the visitors participating in the film festival and the "family" dimension. The highness of the education of the visitors that are participating in the film festival, can be interpreted as its affecting the "family" dimension. In the flower festival, there is no significant difference between the education level and the "socialising" dimension.

Yuan et al. (2005:52-53), in their research, stated that the dimensions of "escaping" and "wine" revealed difference as per the monthly family income of the visitors participating in the event. In the research, there is no significant difference between the monthly income of the visitors participating in the event and the motive of the participation in an event.

It is expected that, by shedding light on the event tourism that is realized in Izmir, this study shall make contribution to the event tourism of Izmir in a planned way as a source, which scrutinizes the motives of the 
individuals participate in the events and indicate some problems that can be encountered as well as offering suggestions. The contribution of the research to the literature; is to scrutinize the different participation motives as per the event types more than one and make comparisons between them, and thus set an example to the researches that shall be made on the economic, social and cultural contributions of the events. On the other hand, its being a study about Izmir, which is a tourism center and attract attention by its events, is another considerable contribution. When evaluated with regard to the sector, the research carries importance as the private sector's learning about the participant motives that indicate why to develop the events oriented toward the motives and the market segmentation in relation with the participant profile is required. By learning the participant motives of the private sector by considering the contribution of the study to the sector, it is thought that they have to develop the events oriented toward the motives. In this context, an information concerning the participant profile should be provided and market segmentation should be made. As the effective management of the event tourism that is realized in the city of Izmir can be discussed, also its sustainability can be provided. For example, the hotel managements should be in the preparations which are convenient to the target market as per the visitors who shall make accommodation. The local contribution of the research to the local administration is the prediction that the type of the events and the participant profile provide in respect to the event planning and administration. Making the necessary briefing and giving support to the private sector on the subject of the events by the local authorities, shall be useful for the event tourism.

The research that has been made is limited with the three types of events which are organised in the province of the Izmir city, the reliability of the collected data, the features of the questionnaire technique, the person who applies it and the answers that the persons give to the questionnaire which are included in the scope of the sampling. The findings obtained concerning the subject are limited with the perception and views of the local visitors during the event. For future studies it is suggested that addressing to a larger population , targeting at the groups which involve diversity having both international and local visitors, could make considerable contribution to the literature. 


\section{REFERENCES}

Alan, U. (2006). Motivasyon Teorileri ve Motivasyonun İs Hayatı Üzerindeki Etkileri. Yüksek Lisans Tezi. İstanbul : Beykent Üniversitesi Sosyal Bilimler Enstitüsü.

Backman, K., Backman, S. J., Uysal, M. ve Sunshine, K. M. (1995). Event Tourism: An Examination of Motivations and Activities. Festival Management and Event Tourism, 3(1): 15-24.

Chang, J. (2006). Segmenting Tourists to Aboriginal Cultural Festivals: An Example in the Rukai Tribal Area, Taiwan. Tourism Management, 27(6): 1224-1234.

Chang, W. (2011). A taste of tourism: Motivations to Attend a Food Festival. Event Management, 15: 151-161.

Crompton, J. L. ve Mckay, S. L. (1997). Motives of Visitors Attending Festival Events. Annals of Tourism Research, 24(2): 425-439.

Dogan, H. Z. (2004). Turizmin Sosyo-Kültürel Temelleri. Ankara: Detay Yayınc1lık.

Esba, M. (2009). Turizm İsletmelerinde Yöneticilerin Duygusal Zekalarının Örgüt Kültürü Üzerindeki Etkisi. Yayınlanmamıs Yüksek Lisans Tezi. İzmir: Dokuz Eylül Üniversitesi Sosyal Bilimler Enstitüsü.

Formica, S. ve Uysal, M. (1996). A Market Segmentation of Festival Visitors: Umbria Jazz Festival in Italy. Festival Management \& Event Tourism, 3(4): 175-182.

Formica, S. ve Uysal, M. (1998). Market Segmentation of an International Cultural- Historical Event in Italy. Journal of Travel Research, 36(4): 16-24.

Getz, D. (2008). Event Tourism: Definition, Evolution and Research. Tourism Management, 29(3): 403-428.

Hall, C. M. ve Page S. J. (2006). The Geography of Tourism and Recreation: Environment, Place and Space. London : Taylor \& Francis e-Library.

http://www.gazete5.com/haber/12.-uluslararasi-izmir-film-festivali-haberleri-

207996.htm, (10.07.2012).

Karaegemen, G. “Film Festivali ödülünü Nar aldı’', www.haberekspres.com.tr/film-festivali-odulunu-naraldi.htm, (10.07.2012).

Koçel, T. (2010). Işsletme Yöneticiliği. İstanbul: Beta Yayınevi.

Kondalkar, V. G. (2009). Organization Effectiveness and Change Management. New Delhi : PHI Learning.

Kulle, M. 'İzmir'in simgesi boyoz festivalle taçlanıyor', http://www.yeniasir.com.tr/Sarmasik/2012/05/04/izmirin-simgesi-boyozfestivalle-

taclaniyor, (24.07.2012).

Lee, C.K. (2000). A Comparative Study of Caucasian and Asian Visitors To A Cultural Expo In An Asian Setting. Tourism Management, 21: 169.

Lee, C. K., Lee, Y. K. ve Wicks, B. E. (2004). Segmentation of Festival Motivation by Nationality and Satisfaction. Tourism Management, 25(1): 61-70.

McMorland, L. A. ve MacTaggart, D. (2008). Traditional Scottish Music Events: Native Scots Attendance Motivations. Event Management, 11(1/2): 57-69.

Mohr, K., Backman, K. F., Gahan, L. W. ve Backman, S. J. (1993). An Investigation of Festival Motivations and Event Satisfaction by Visitor Type. Festival Management \& Event Tourism, 1(3): 89-97.

Nicholson, R. E. ve Pearce, D. G. (2001). Why Do People Attend Events: A Comparative Analysis of Visitor Motivations at Four South Island Events. Journal of Travel Research, 39 : 449-460.

Nunnally, J.C. (1978). Pschometric Theory. New York: Mc Graw-Hill, Second Edition

Olalı, H. ve Timur A. (1988). Turizm Ekonomisi. İzmir: Ofis Ticaret Matbaacilık.

Park, S. H. (2009). Segmentation of Boat Show Attendees by Motivation and Charactesristics: A Case of New York National Boat Show. Journal of Convention \& Event Tourism, 10(1): 27-49.

Park, K. S., Reisinger Y. ve Kang H. J. (2008). Visitors' Motivation for Attending the South Beach Wine and Food Festival, Miami Beach, Florida. Journal of Travel \& Tourism Marketing, 25(2): 161-181.

Pearce, P. L. ve Lee, U. (2005). Developing the Travel Career Approach to Tourist Motivation. Journal of Travel Research, 43(3): 226-237.

Ralston, L. ve Crompton, L.J. (1988). Motivations, service quality and economic impact of visitors to the 1987 Dickens on the strand emerging from a mail-back survey. Report number 3 for the Galveston Historical Foundation. College Station, TX: Texas A\&M University.

Rizaoglu, B. (2003). Turizm Davranısı. Ankara: Detay Yayıncılık.

Ryan, C. (1998). Travel Career Ladder: An Appraisal. Annals of Tourism Research, 25(4): 936-957.

Schneider, I. E. ve Backman, S. J. (1996). Cross- Cultural Equivalence of Festival Motivations: A Study in Jordan. Festival Management \& Event Tourism, 4(3/4): 139-144. 
Scott, D. (1996). A Comparison of Visitor Motivations to Attend Three Urban Festivals. Festival Management \& Event Tourism, 3: 121-128.

Singh, L. K. (2008). Fundemental of Tourism and Travel. India : ISHA Books

Singh, L. K. (2008). Management of Travel Agency. India : ISHA Books

Snipes, R. L. ve Ingram, R. (2007). Motivators of Collegiate Sport Attendance: A Comparison across Demographic Groups, Innovative Marketing, 3(2): 65-74.

Tassiopoulos, D. ve Damster, G. (2005). Event Management: A Professional and Developmental Approach. Cape Town : Juta Academic.

Thomson, K., ve Schofield, P. (2009). Segmenting and Profiling Visitors to the Ulaanbaatar Naadam Festival by Motivation. Event Management, 13(1): 1-15.

Usta, Ö. (2009). Turizm: Genel ve Yapısal Yaklasım. Ankara: Detay Yayıncılık.

Uysal, M., Gahan, L. W., ve Martin, B. (1993). An Examination of Event Motivations: A Case Study. Festival Management \& Event Tourism, 1(1): 5-10.

Uysal, N. "Çiçek Festivali'ne 1 milyon ziyaretçi”', http://www.yeniasir.com.tr/KentHaberleri/2012/05/01/cicekfestivaline-1-

milyon-ziyaretci, (24.07.2012).

Yuan, J., Cai, A. C., Morrison A. M. ve Linton S. (2005a). An Analysis of Wine Festival Attendees' Motivations: A Synergy of Wine, Travel and Special Events?. Journal of Vacation Marketing, 11(1): 41-58. 